\title{
神経系前駆細胞における機能的グルタミン酸シグナリング
}

\author{
中道範隆
}

\section{Functional Glutamate Signaling in Neural Progenitor Cells}

\author{
Noritaka NAKAMICHI \\ Laboratory of Molecular Pharmacology, Division of Pharmaceutical Sciences, \\ Kanazawa University Graduate School of Natural Science and Technology, \\ Kakuma-machi, Kanazawa, Ishikawa 920-1192, Japan
}

(Received May 31, 2011)

\begin{abstract}
In this review, we have summarized our recent studies on the functionality of ionotropic (iGluR) and metabotropic (mGluR) glutamate receptors expressed by undifferentiated neural progenitor cells (NPC) isolated from embryonic rat and mouse brains. NPC are primitive cells with the self-renewal capacity as well as the multipotentiality to generate different neural lineages including neurons, astrocytes, and oligodendrocytes. Isolated cells were cultured in the presence of growth factors for the formation of round spheres by clustered cells so-called 'neurospheres' under floating conditions. Reverse transcription polymerase chain reaction analyses revealed expression of mRNA for particular iGluR and mGluR subtypes in NPC. Moreover, sustained exposure to an agonist for the $N$-methyl-D-aspartate receptor (NMDAR) not only inhibited the formation of neurospheres but also promoted differentiation of NPC into cells immunoreactive to a neuronal marker protein on immunocytochemistry and western blot analyses. On the other hand, sustained exposure to an agonist for the group III mGluR subtype led to suppression of proliferation activity in these neurospheres along with facilitation of the subsequent differentiation into astrocytes. Accordingly, glutamate could play a pivotal role in the mechanisms underlying proliferation for self-replication, together with determination of the subsequent differentiation fate toward particular progeny lineages through activation of NMDAR and group III mGluR subtypes in NPC.
\end{abstract}

Key words_— neural progenitor cell; glutamate; neurogenesis; neurodegenerative disorder; regenerative medicine

\section{1. はじめに}

アルツハイマー病やパーキンソン病等の難治性中 枢神経変性疾患を発症することにより大量の神経細 胞死が引き起こされるため, このような病態罹患時 には患者が病気の進行とともに社会生活から脱落す るという由タしき事態に陥つてしまう。また，患者 が社会生活から脱落するに従い近親者による介護が 必要不可欠となり, 患者及び介護者の quality of life は著しく低下する。しかしながら，このような 疾患の治療は対症療法がほとんどであり，根本的治 療法はいまだ確立されていないのが現状である。そ の一因として,「哺乳動物成体の中枢神経は一度損

金沢大学医薬保健研究域薬学系薬物学研究室 (T9201192 石川県金沢市角間町)

現所属：同分子薬物治療学研究室

e-mail: nakamiti@p.kanazawa-u.ac.jp

本総説は, 平成 22 年度日本薬学会北陸支部学術奨励賞

の受賞を記念して記述したものである.
傷を受けると再生しない」ことが挙げられる（Fig. 1)。一方，近年ヒトを含む哺乳動物成体脳において も，海馬歯状回や側脳室下帯に神経系前駆細胞 (neural progenitor cells; NPC) が存在し，さらに神 経新生が起こっていることが明らかとなってき た. ${ }^{1-3)}$ 実際にわれわれの検討においてもラットの 海馬歯状回や側脳室下带において，増殖性細胞の指 標となる bromodeoxyuridine (BrdU) の取り込みを 示す細胞やNPC に特異的なマーカータンパク質で ある nestin を発現する細胞が多数観察された。 NPC は, 神経細胞, アストロサイト, オリゴデン ドロサイトの 3 種類の中枢神経系構成細胞に分化す ることができる多分化能を有しており，この多分化 能を保持しながら増殖を繰り返すことのできる自己 複製能を有する未分化な細胞として定義される。し たがって，哺乳動物成体脳に存在するNPC から神 経細胞への分化を促進すること，あるいは NPC か 


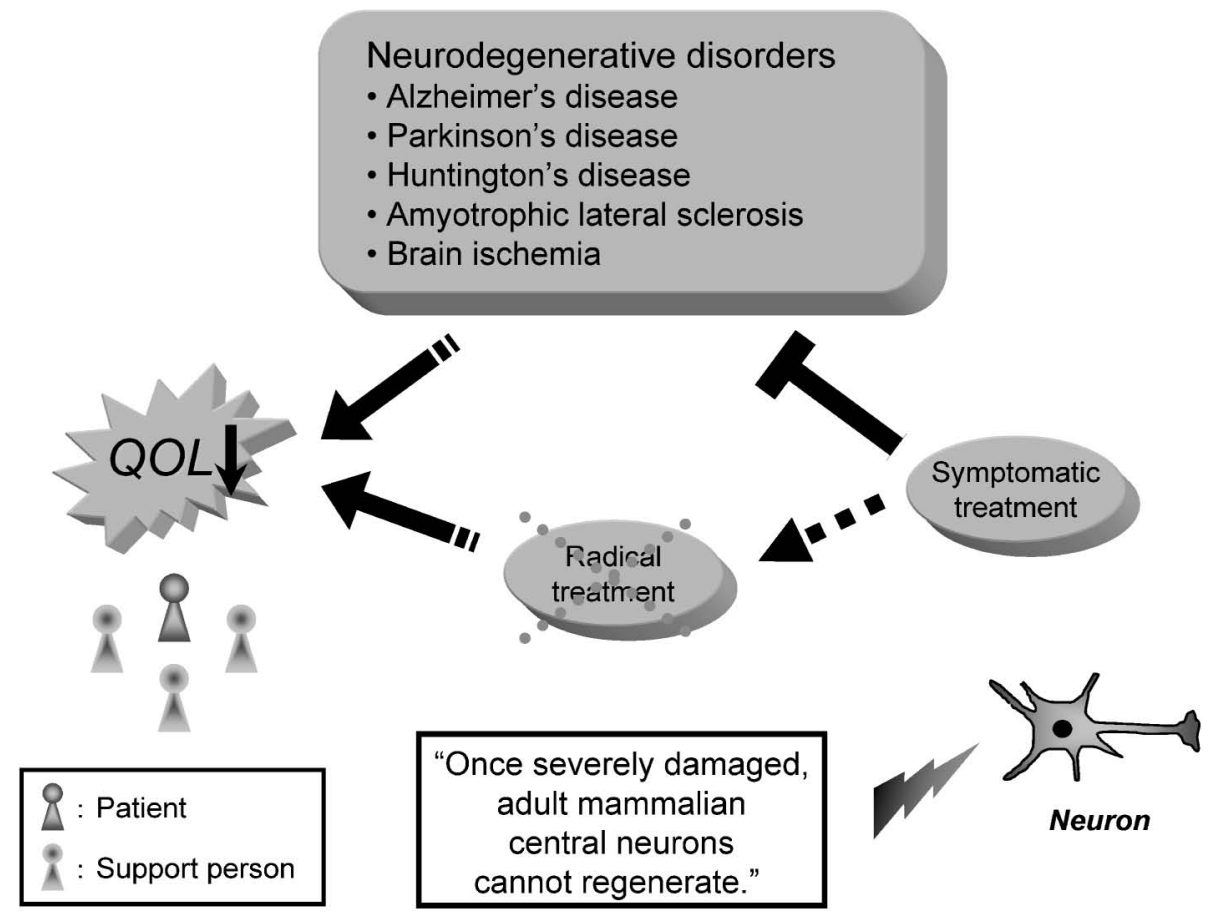

Fig. 1. Circumstances of the Patients Suffering from Neurodegenerative Disorders

ら分化させた神経細胞を移植することができれば, 中枢神経変性疾患の根本的治療法の確立につながる と考えられる.

グルタミン酸（Glu）は哺乳動物中枢神経系にお いて，アミノ酸代謝やエネルギー産生あるいはタン パク質生合成など細胞の普遍的現象に関与している だけでなく，興奮性神経情報伝達物質及び内因性工 キサイトトキシンとしての特異的機能も有する. ${ }^{4,5)}$ Glu による細胞外興奮性シグナルは, 細胞膜上に存 在する Glu 受容体 (GluR) により細胞内シグナル に変換され, 細胞核へと伝達される. GluR は特定 イオンの細胞膜透過性を調節するイオノトロピック 型 (iGluR), 及び細胞内の特定リン脂質加水分解 や細胞内環状ヌクレオチド代謝を制御する guanosine-5'-triphosphate タンパク共役メタボトロピック 型（mGluR）に大別される. ${ }^{4-6)}$ iGluR はさらに外 因性アゴニストに対する感受性の相違などにより， $N$-methyl-D-aspartate（NMDA）感受性受容体 (NMDAR）と NMDA 非感受性受容体（non-NMDAR） に分類される。 NMDAR にはサブユニットとして NR1 サブユニットと NR2A-D, 3A，3B サブユニッ トが見い出されており, 機能的な NMDAR の発現 には NR1 が必須である. ${ }^{7,8)}$ NR1 は NR2A-D, 3A， $3 \mathrm{~B}$ 中の 1 種あるいは数種のサブユニットとへテロ
メリックな複合体を形成し，様々なチャネル機能の 調節を行う。また, non-NMDAR には, その薬理 学的性質の差異により, GluR1-4 サブユニットか ら構成される DL- $\alpha$-amino-3-hydroxy-5-methylisoxazole-4-propionateic acid 受容体（AMPAR）及び GluR5-7, KA1, 2 から構成されるカイニン酸受容体 (KAR) が存在する。一方, mGluRには, 現在の ところ 8 種類のサブユニット（mGluR1-8）の存在 が知られているが，そのアゴニスト感受性の相違, アミノ酸配列の相同性，あるいは共役する細胞内セ カンドメッセンジャーの違いなどから, さらに 3 種 類のサブタイプに分類される。すなわち，イノシ トール 1, 4, 5-三リン酸とジアシルグリセロールの 生成を促進するグループ I (mGluR1，5）と，いずれ も cAMP の生成を抑制するグループ II（mGluR2, 3）及びグループ III（mGluR4, 6, 7, 8) である. ${ }^{7,8}$

GluR を介するシグナル入力が神経細胞において 重要な役割を果たすことは周知の事実であるが，近 年神経細胞ばかりでなく他の中枢神経系構成細胞, アストロサイトにおいても Glu シグナルが重要な 役割を担っている可能性が報告されている.9,10) そ こでわれわれは機能的な GluR が NPCにも発現し ており，増殖能及び分化能を制御している可能性に ついて検討を加えた. ${ }^{11-13)}$ 本総説では, 哺乳動物中 
枢神経において重要な役割を果たしている Glu シ グナル入力が NPC においても重要な役割を果たし ている可能性について，ラットあるいはマウス大脳 皮質より単離した培養 NPC を用いて検討したわれ われの研究成果を中心に報告したい。

2. イオノトロピック型グルタミン酸受容体シグ ナル

ラット大脳皮質より単離直後の NPCには, NMDAR 及び AMPAR を構成するいずれのサブユ ニットの mRNA 発現も確認された。 KAR 構成サ ブユニットに関しては，GluR6 のみ発現が認めら れなかった。iGluRの 3 種類のサブタイプである NMDAR, AMPAR, KAR に特異性の高い各アゴニ スト NMDA，AMPA，KA を NPC に持続的に曝露 したところ，NMDAのみが有意にミトコンドリア 活性を低下させた。一方，いずれの iGluR アゴニ ス卜曝露も，細胞死の指標となる lactate dehydrogenase（LDH）の細胞外への放出には顕著な影響を 及ぼさなかった。 NMDA の持続的曝露は，NPC が in vitro 培養条件下で示す特徵の 1 つである神経塊 (neurospheres) の形成や BrdU の取り込み活性を 有意に阻害した。この NMDAによる阻害は，

NMDAR の特異的アンタゴニストである MK-801 の同時添加により，いずれも NMDA 非曝露群と同 程度にまで回復した。NMDA 曝露が細胞生存率に は影響せずにミトコンドリア活性，神経塊形成ある いは BrdU 取り込みといつた細胞増殖能の指標を阻 害したことから，NPCには機能的な NMDAR が発 現しており，NMDAR シグナル入力が細胞の増殖 能を負に制御している可能性が考えられる. ${ }^{11,13)}$

次に, NMDAR シグナル入力が NPC の分化能に 及ぼす影響について考察する．NMDA を持続的に 曝露した NPC を細胞増殖因子非存在下で接着培養 を行うことにより，細胞分化を誘導した．分化誘導 前にNMDA を持続的に曝露した細胞群では対照群 と比較して，神経細胞マーカーとして用いた microtubule-associated protein 2 (MAP-2) 抗体陽性 細胞数が増加し，アストロサイトマーカーとして使 用した glial fibrillary acidic protein (GFAP) 抗体陽 性細胞数が減少した。また，同抗体を使用したウェ スタンブロッティング法による解析でも，NMDA 曝露群では MAP-2 抗体陽性タンパクの発現量が増 加し, GFAP の発現量は減少した。また，NPC 培
養時に NMDA 存在下で培養を行うと, 分化誘導後 に NMDA 応答性に細胞内遊離 $\mathrm{Ca}^{2+}$ 濃度上昇を示 す細胞数が倍程度に増加した。したがって, NMDAR シグナル入力は NPC の神経細胞への分化 能を促進する可能性が考えられる. ${ }^{11,13)}$

3. メタボトロピック型グルタミン酸受容体シグ ナル

マウス大脳皮質より単離直後の NPC には，グ ループI 及びグループ II を構成するいずれの mGluR サブユニットの mRNA 発現も確認され た。グループ III mGluR 構成サブユニットに関し ては，mGluR4 及び 8 の発現は確認できたが, mGluR6 及び 7 の発現は認められなかった。 mGluR の 3 種類のサブタイプであるグループ I, グループ II，グループ III に特異性の高い各アゴニ スト DHPG, DCG-IV, L-AP4 を NPC に持続的に 曝露したところ，L-AP4 のみが有意にミトコンド リア活性を低下させた。一方，いずれの mGluRア ゴニスト曝露も，LDH の培地中への放出に著明な 変化を与えなかったＬ-AP4 の持続的曝露は，ミ トコンドリア活性だけでなく神経塊の形成や BrdU の取り込み活性も有意に阻害したが，グループ III mGluR の特異的アンタゴニストである CPPG の同 時添加により，いずれも L-AP4 非曝露群と同程度 にまで回復した.グループ III mGluR シグナル入 力が分化能に及ぼす影響についても検討したところ, L-AP4 を持続的に曝露した細胞群では，MAP-2 抗 体陽性細胞数が減少し, GFAP 抗体陽性細胞数が 増加した。したがって，NPCには機能的なグルー プ III mGluR が発現しており，同受容体を介する シグナル入力が細胞の増殖能を負に制御する可能性 及びアストロサイトへの分化能を促進する可能性が 考えられる (Fig. 2).12,13)

グループ III mGluR の活性化に伴い, 細胞内の cAMP 生成が抑制される。cAMP は細胞内セカン ドメッセンジャーとして広く知られており，その下 流シグナルカスケードとして protein kinase A （PKA）の活性化， cAMP response element binding protein (CREB) のリン酸化を介し，CRE 配列をプ ロモーター領域に有する遺伝子の発現を調節するこ とによって種々の生理的変化を引き起こす，中枢神 経系においても cAMP を介するシグナル伝達が, 神経細胞の生存や神経突起の伸長, 神経保護因子の 


\section{Group III mGluR signaling}

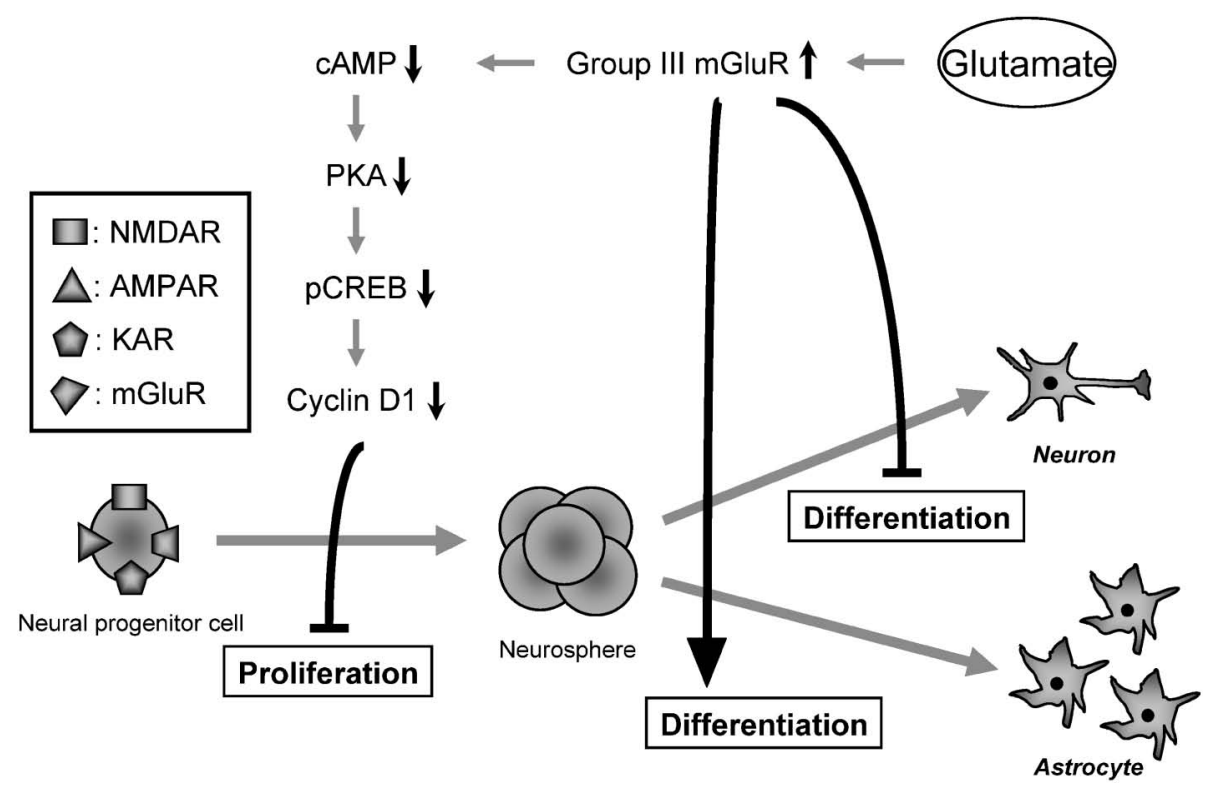

Fig. 2. Signaling Machineries Mediated by Group III mGluR in NPC

分泌や学習・記憶の形成等に深く係わることが報告

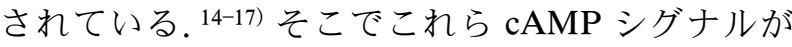
NPC の増殖能及び分化能に及ぼす影響についても 検討を加えた。細胞内の cAMP 濃度を上昇させる forskolin (FK), dibutyl-cAMP あるいは下垂体アデ ニル酸シクラーゼ活性化ポリペプチド（PACAP） を NPC に曝露することにより，ミトコンドリア活 性の有意な上昇及び神経塊の形成促進が認められた。 FK による増殖能の増大は, L-AP4 あるいは PKA 阻害剂である $\mathrm{H} 89$ を同時曝露することにより有意 に抑制された。さらに，細胞周期制御タンパク質で あり細胞増殖時に発現が誘導される Cyclin D1 の関 与についても検討を加えたところ， L-AP4 曝露群 では対照群と比較して Cyclin D1 の mRNA 発現量 及びプロモーター活性の有意な減少が認められたの に対して, FK 曝露群では mRNA 発現量及びプロ モーター活性の有意な増加が認められた。また, CRE 配列の下流にレポーター遺伝子を組夕込んだ コンストラクトを用いた解析により，L-AP4 は CRE 配列下流の転写を抑制するが，FK は逆に促進 することが明らかとなった。一方，分化能に対する 影響についても検討したところ，FK 曝露群では LAP4 曝露群とは逆に, MAP-2 陽性細胞数が増加し, GFAP 陽性細胞数は減少した。以上の結果より,
cAMP シグナルは PKA の活性化， CRE 配列を介 した遺伝子転写制御，Cyclin D1 の転写活性化を介 して，NPC の増殖能及び神経細胞への分化能を促 進する可能性が示された。また，グループ III mGluR はこの cAMP シグナル伝達経路を抑制する ことにより，NPC の増殖能を負に制御あるいはア ストロサイトへの分化能を促進しているものと推察 される (Fig. 2).12,13)

\section{4. おわりに}

2010 年 10 月，米国において世界で初めてヒト胚 性幹細胞（ES 細胞）由来のオリゴデンドロサイト 前駆細胞を用いた春髄損傷患者に対する臨床試験が 開始された．幹細胞の移植による難治性疾患の治療 はもはや夢物語ではなく，今後急速に臨床使用に向 けて進展することが予測される。幹細胞の移植療法 が実現化すれば，移植に必要な細胞を効率よく作製 する方法が必要となる。また，移植における大きな 問題点として，移植細胞に対する拒絶反応が挙げら れる.この問題を回避するための方法の 1 つとし て，目的とする細胞の前駆細胞を移植し，生体内で 薬物投与により増殖させた後, 目的細胞へと分化さ せるアプローチが有効となるかもしれない，移植療 法だけでなく，哺乳動物の中枢神経系が形成される 胎生期において，NPC の正常な増殖や分化が重要 
であることは言うまでもない。したがって，NPC の増殖・分化を制御するシグナル異常が，発達障害 の一因となる可能性は十分に考えられる，また，成 体脳においても，強烈なトラウマ体験後に一過性に NPC の数が減少することが，心的外傷後ストレス 障害（PTSD）の発症に関与している可能性が報告 されている. ${ }^{18)}$ 以上のように，本総説で紹介した NPC の増殖や分化を制御するシグナルの解明研究 は，種々の神経変性疾患の発症機構解明及び治療の 両面において非常に重要な意義を持つ.

われわれの研究グループは，ラットあるいはマウ ス大脳皮質由来 NPC に機能的な NMDAR あるい はグループ III mGluR が発現しており, 細胞の増 殖能及び分化能を制御している可能性を示し た. ${ }^{11-13)}$ 今後はヒト ES 細胞あるいは人工多能性幹 細胞（iPS 細胞）由来の NPC でも GluR シグナル 入力によって増殖・分化能が調節されているのかを 検討する必要がある．また，より効率的に細胞を増 殖・分化させるためには, Glu シグナルだけでな $<$, 他の NPC 増殖・分化調節シグナルとの相互作 用を調べることも重要である。われわれは既に NPC の増殖・分化能が，抑制性神経情報伝達物質 である $\gamma$-amino butylic acid（GABA）あるいは静的 磁場曝露によっても調節されることを報告してい る. ${ }^{19-21)}$ 今後, NPC の増殖・分化に関する基礎的 メカニズム解明研究をさらに発展させることによ り，各種中枢神経変性疾患に対する根本的治療法の 確立が期待される.

謝辞本研究を遂行する上において終始ご留切 なるご指導とご鞭撻を賜りました，金沢大学医薬保 健研究域薬学系・米田幸雄教授及び加藤将夫教授に 厚く御礼申し上げます。また，多大なるご協力とご 援助を頂きました金沢大学医薬保健研究域薬学系・ 薬物学研究室及び分子薬物治療学研究室の皆様に深 く感謝いたします。

\section{REFERENCES}

1) Gage F. H., Kempermann G., Palmer T. D., Peterson D. A., Ray J., J. Neurobiol., 36, 249 -266 (1998).

2) Garcia-Verdugo J. M., Doetsch F., Wichterle H., Lim D. A., Alvarez-Buylla A., J. Neu- robiol., 36, 234-248 (1998).

3) Johansson C. B., Momma S., Clarke D. L., Risling M., Lendahl U., Frisen J., Cell, 96, 25 -34 (1999).

4) Hollmann M., O’Shea-Greenfield A., Rogers S. W., Heinemann S., Nature, 342, 643-648 (1989).

5) Yoneda Y., Yakugaku Zasshi, 113, 469-488 (1993).

6) Nakanishi N., Shneider N. A., Axel R., Neuron, 5, 569-581 (1990).

7) Hollmann M., Heinemann S., Annu. Rev. Neurosci., 17, 31-108 (1994).

8) Yoneda Y., Kuramoto N., Kitayama T., Hinoi E., Prog. Neurobiol., 63, 697-719 (2001).

9) Lee M. C., Ting K. K., Adams S., Brew B. J., Chung R., Guillemin G. J., PLoS One, 5, e14123 (2010).

10) Xi Q., Tcheranova D., Basuroy S., Parfenova H., Jaggar J. H., Leffler C. W., Am. J. Physiol. Heart Circ. Physiol., 2011. (in press)

11) Yoneyama M., Nakamichi N., Fukui M., Kitayama T., Georgiev D. D., Makanga J. O., Nakamura N., Taniura H., Yoneda Y., $J$. Neurosci. Res., 86, 2392-2402 (2008).

12) Nakamichi N., Yoshida K., Ishioka Y., Makanga J. O., Fukui M., Yoneyama M., Kitayama T., Nakamura N., Taniura H., Yoneda Y., J. Neurochem., 105, 1996-2012 (2008).

13) Nakamichi N., Takarada T., Yoneda Y., J. Pharmacol. Sci., 110, 133-149 (2009).

14) Kandel E. R., Science, 294, 1030-1038 (2001).

15) Mabuchi T., Kitagawa K., Kuwabara K., Takasawa K., Ohtsuki T., Xia Z., Storm D., Yanagihara T., Hori M., Matsumoto M., $J$. Neurosci., 21, 9204-9213 (2001).

16) Reppert S. M., Weaver D. R., Annu. Rev. Physiol., 63, 647-676 (2001).

17) Kida S., Josselyn S. A., Pena de Ortiz S., Kogan J. H., Chevere I., Masushige S., Silva A. J., Nat. Neurosci., 5, 348-355 (2002).

18) Tamaki K., Yamada K., Nakamichi N., Taniura H., Yoneda Y., J. Neurochem., 105, 1642-1655 (2008).

19) Fukui M., Nakamichi N., Yoneyama M., Yoshida K., Ozawa S., Kitayama T., Nakamura N., Taniura H., Yoneda Y., J. Neurosci. Res., 86, 2615-2623 (2008). 
20) Fukui M., Nakamichi N., Yoneyama M., Ozawa S., Fujimori S., Takahata Y., Nakamura N., Taniura H., Yoneda Y., J. Cell. Physiol., 216, 507-519 (2008).
21) Nakamichi N., Ishioka Y., Hirai T., Ozawa S., Tachibana M., Nakamura N., Takarada T., Yoneda Y., J. Neurosci. Res., 87, 24062417 (2009). 